\title{
The Linkages Between Commitment to Sustainability, Organizational Culture, Quality Management, and Organizational Performance
}

\author{
Lillian Y. Fok, PhD
}

Western Washington University, Bellingham, Washington, United States

(iD) https://orcid.org/oooo-0002-1154-2978

Yun-Chen T. Morgan, PhD

Southeastern Louisiana University, Hammond, Louisiana, United States

(iD) https://orcid.org/0000-0002-1455-0543

Susan M. L. Zee, PhD

Southeastern Louisiana University, Hammond, Louisiana, United States

(iD) https://orcid.org/oooo-0002-7276-0573

Contact:fokl@wwu.edu

\section{Abstract}

The growing economic pressures, rising awareness of the importance of environmental protection, and stringent global regulations are leading to more integration of sustainability initiatives into corporate strategies across multiple industries. These sustainability initiatives can alter organization cultures and affect employee perceptions and organizational outcomes. In this study, 331 respondents from a wide variety of industries in the South were surveyed. Results showed that companies' overall green/sustainability orientation is related to organizational culture, quality management maturity, and companies' performance. The findings implied that it is imperative to develop an organizational culture that is supportive of quality and sustainability to ensure the success of the green initiatives.

Keywords: sustainability, sustainability performance, quality management, organizational culture

Date Submitted: December 16, 2020 | Date Published: November 9, 2021

\section{Recommended Citation}

Fok, L. Y., Morgan Y.-C. T., \& Zee, S. M. L. (2021). The linkages between commitment to sustainability, organizational culture, quality management, and organizational performance. International Journal of Applied Management and Technology, 2O(1), 105-123. https://doi.org/10.5590/IJMAT.2021.20.1.06

\section{Introduction}

Accompanied by the alarm of global warming and the gradual exhaustion of resources, there is an increasing need to balance sustainability and business decisions. Sustainability was coined by Bergquist (2017) as meeting the needs of the present generation without compromising the ability for future generations to meet their own 
needs. In order to respond to the heightened customer awareness and demands, businesses need to place more priority on incorporating green sustainability initiatives in corporate strategies in order to thrive among intense global competitions. Businesses of all sizes realize the importance of sustainability, and thus exploring business strategies to sustain their companies' longevity (Warren \& Szostek, 2017). The green movement is no longer a superficial or short-term focus to alter reputations and increase profit; it has become a vital part of most companies' operations. Green sustainability practices are focused on how raw materials are foraged from the environment with minimal or no harm to nature, made into products or services efficiently with clean production processes, and delivered outputs to final customers maintaining a low carbon footprint. The goal is to manage the entire supply chain to minimize the environmental impact. While "going green" may be costly in the beginning, business leaders realize how the long-term benefits, including enhancing the image of a company, reducing waste and pollution, and increasing production efficiency, would generate bigger savings and competitive advantages (Whitelock, 2019; Yang et al., 2010).

In the new era of sustainability, the green movement takes on a very diverse perspective that can include green manufacturing, sustainable supply chain, green marketing, and green consumer. This study explores the relationships between various organizations' green sustainability orientation and factors within organizations that can be influenced by the degree of green orientation. Specifically, we focus on the connection between the green movement and sustainability issues, and the linkages between green orientation and organizational culture, quality management maturity, organizational impact, and organizational success. Results of this study offer potential insights on organizations' success and failure in carrying out their sustainability initiatives, based on differing factors. "Going green" should not be treated as a one-size-fits-all solution to fix brand images or reputation, nor should it be a quick fix to profitability issues. While green orientation is an inevitable movement for companies to be sustainable, many factors have to be considered simultaneously in order for the initiatives to be successful.

\section{Literature Review}

Several global warnings to humanity have been issued within the last decade, and they are cautions from scientists-not just within a few developed nations but an unprecedented agreement in the scientific community - of the entire world. These warnings forced us to pay attention to the importance of a greener way of living, and this includes how businesses operate. Increased interest in related research includes areas such as green manufacturing (Dief, 2011; Ma et al., 2016; Sen et al. 2015; Sezen \& Cankaya, 2013) and consumer behavior towards green products (Doszhanov \& Ahmad, 2015; Sandu, 2014; Yang, 2017).

Companies choose to practice in greener ways because they realize they can contribute to the preservation of our environment and also increase their profits. Deif (2011) suggested that there are three reasons that justify investing and implementing green manufacturing techniques: efficiency, market share, and government support and regulations. Employing greener manufacturing can save time and money because the idea is to make the same product using fewer resources or energy. New consumer demands and heightened consumer awareness (Ackerman, 1997; Wilson, 2011), combined with increased global competition pressure manufacturing enterprises to review their strategies in order to secure market shares and sharpen their competitive edges. Pressure from governments to evolve into green manufacturing is also increasing. As regulations change, penalties and tax benefits increase, becoming greener at different manufacturing stages may become a mandate rather than an option. Companies worldwide are concerned about the ability to grow and remain profitable and are pressured by stakeholders to be more eco-efficient (Klebnikoff, 1996).

The value or methods of investing in green technology and green transformation may not be universally agreed upon. However, few dispute the notion that green manufacturing can have a profound positive impact on any business. Hoffman (2000) argued that green attempts in manufacturing should be an environmental strategy 
rather than a management approach, thus creating a win-win scenario by which manufacturers can improve environmental performance whilst achieving economic gain. Li et al. (2013) suggested in their information technology and green application research that green practices can help companies increase profits in the long run. Sezen and Cankaya (2013) found that green manufacturing can lead to lower raw material costs, production efficiency gains, and reduced environmental and occupational safety expenses. Further explaining, researchers found that by using a system-wide and integrated approach to reduction elimination of waste streams associated with the design, manufacture, and disposal of materials, companies can improve not only their performance, but also their corporate image. Lamvik et al. (2001) examined ways to achieve innovative eco-friendly solutions and Ma et al. (2016) examined the relationship between carbon sensitive products, emissions, and profit. Ma et al. found that the multi-goal green manufacturing model increased economic benefit while still reduced emissions.

\section{Consumer Attitudes}

Doszhanov and Ahmad (2015) studied various methods to increase consumers' intention of using green products. They found green brand awareness, green brand trust (readiness to depend on the capability or reliability of the product), and green perceived value (the assumed worthiness or judgement of the product) have positive effects on the intention of purchasing eco-friendly products.

Increasingly, advertisers focus on environmental benefits when they sell, such as the promotion of energyefficient light bulbs, biodegradable diapers, and environmentally safe detergents (Laddha \& Malviya, 2015). Ecofriendly products have become the better option in many households; they no longer are the expensive or less practical choices. Green products help realize the green manufacturing objectives in practice. Some (Kangovou, 2017) argue that embedding responsible decision making in consumers not only helps businesses create relationships with them but also benefits families through smarter product choices. Less harsh chemicals, prolonged usage, and healthier lifestyles are among the benefits. Consumers are aware of the potentially higher investments in eco-friendly products; however, the use of these products is often more cost efficient in the long run. Reusable coffee cups and grocery bags are prime examples. For customers who are not interested in preserving the environment, eco-friendly products can still be marketed as products that are more efficient and long-lasting compared to their competitions, in addition to being green.

\section{Total Quality Management (TQM) and Sustainability}

Total quality management (TQM) has its roots in the integrative approach in customer satisfaction and a company's overall success (Chin et al., 2001; Sanuri Mohd Mokhtar et al., 2013). Organizations are constantly facing intense pressure from competition, and they realize the need to incorporate sustainable development and TQM in order to reach higher levels of improvement and ultimate profitability (Hitchcock \& Willard, 2002; Jonker, 2000; McAdam \& Leonard, 2003). It is a logical continuation of research to expand TQM into a concept that also includes sustainability, long-term survival, and growth with the emphasis of globalizing economies (Dervitsiotis, 2001; Wilkinson et al., 2001; Zairi, 2002).

Sustainable development is necessary for companies to address environmental deterioration. Zairi and Liburd (2001) defined sustainability development as the ability of an organization to adapt to change in the business environment in order to deploy the best contemporary methods to achieve and further maintain superior performance. Their take on sustainability development implies competitiveness-and an organization's competitiveness-is partly dependent on their quality management practices. Sustainability is a new tool in company planning (Beatley \& Manning, 1997) and a fundamentally important concept that should influence all policy developments within a firm (Loffler, 1998).

Employee attitudes regarding green initiatives may be influenced by their perceptions toward TQM programs implemented in the workplace. Previous research examined employee involvement (Rapp \& Eklund, 2002), human resource management and leadership (Daily \& Huang, 2001), commitment (Matta et al., 1996), and 
personality traits (Ahmad \& Schroeder, 2002) all expressed possible connections between perceptions and attitudes. How employees perceive the effectiveness of varying TQM tools employed in the workplace should have significant consequences on employee attitudes about going green.

In addition, recent research showed important underlying issues involving the depth or qualitative aspects of an organization's experience with quality management (QM)-a term referred to as QM maturity (Fok et al., 2000). Specifically, Fok et al. (2000) reported the importance of distinguishing between the length of time an organization reported deploying quality management tools and the quality of its implementation.

\section{Organizational Culture, Total Quality Management (TQM), and Sustainability}

Organizational culture is an excellent tool to establish routines that link quality to performance (Polites \& Karahanna, 2013) and can be used to integrate regulations and standards into everyday operations, while also maintaining a high level of performance and productivity (Valmohammadi \& Rshanzamir, 2015). High commitment to product quality is essential to strengthening organizational performance (Hofmann \& Oldehaver, 2016). Leaders within a company and their employees need to establish an understanding of shared behaviors rooted in a culture of quality excellence (Rashid \& Aslam, 2012) in order to increase commitment to quality. Leadership and teamwork need to align with organizational goals and congruent behaviors among employees are needed to achieve an effective organizational culture (Schmiedel et al., 2013).

In the Macht and Davis (2018) research, the authors discussed strategies to influence a quality compliance culture and acknowledged the importance of knowledge management, habit, and organizational effectiveness and how they link to organizational culture. Just as organizational culture is unique and difficult to duplicate, organizational knowledge is also unique and could be a great instrument to utilize in adding value (Macht \& Davis, 2018; Biotto et al., 2012). If leaders within an organization can ensure uniformity in understanding and application of standardized procedures, enterprise culture can be enhanced, innovation can be stimulated, and good habits can be formed that lead to quality issues being reduced (Macht \& Davis, 2018). When sustainability becomes a part of a company's core strategy, the culture that binds the employees together can have a great impact on the level of success on sustainability initiatives. When the association between commitment to quality and information sharing, continuous improvement, and teamwork was examined by Malik and Blumenfeld (2012), a positive connection was found between the integration of quality management practices embedded in organizational culture (Macht \& Davis, 2018). An organizational culture that emphasizes performance measurement and quality management should ultimately lead to higher levels of organizational effectiveness.

In this research, we explore the relationships among green orientation and organizational culture, impact, performance, and QM maturity. We posit that organizational culture may impact employee perceptions of the green movement and its importance to the organization, as well as performance outcomes.

\section{Research Model}

In this study, we extend the examination of green movement issues to consider (a) organizational culture, (b) employee perceptions of organizational commitment to sustainability (green movement), and (c) the relationships that may exist between personal and organizational commitment and the QM maturity of the organization. When there is a higher level of perceived commitment to sustainability (green movement) and more mature QM systems are in place, we expect organizations to perform better and the impact of the green movement will be perceived as favorable. Thus, QM and perceptions of the organization's green movement will be seen as having positive impacts upon organizational outcomes. 


\section{Composite Research Framework}

Organizational culture can be strategically established to reach certain goals. It is often used as a tool to encourage routines that promote organizational objectives. Company leaders who wish to ensure uniformity in the application of sustainability procedures and results can do so through stimulating a culture in which the institution emphasizes greener operations. The level of success an organization is able to achieve through building an impactful and relevant culture could dictate the supportiveness among leadership and between employees. In the proposed research framework, we argue that the green movement within the organization should be related to or affected by the organizational culture (Research Question 1, labeled as RQ1, in Figure 1), and organizations with more desirable culture should be more supportive of the green movement (Research Question 5, labeled as RQ5, in Figure 1).

Organizational culture is associated with performance through its influence on members' attitudes and behaviors. The strength of culture is important in explaining the performance of the company. We expect that organizational culture is related to the organization's performance in general (Research Question 6, labeled as RQ6, in Figure 1).

Research Question 1: Organizational green orientation is related to organizational culture.

Research Question 5: Organizations that are described by employees as higher in organizational culture will also report more positive feelings about the impact of the green movement.

Research Question 6: Organizations that are described by employees as higher in organizational culture will also report more positive feelings about the organization's performance.

As companies become more green-oriented, these changes can lead to a more positive image and a stronger reputation as perceived by both their customers and employees. The organization itself will be seen as "doing better" in general, and the impact of the green movement will be more profound. In the proposed research framework, we argue that employees in organizations with higher green orientation will report more positive feelings about the impact of sustainability practices and better performance. Employees who feel they work for an organization with high performance will feel more positively about the sustainable impact they are making (Research Questions 2, 3, and 4, labeled as RQ2, RQ3, and RQ4, in Figure 1).

Research Question 2: Organizations that are described by employees as higher in organizational green orientation will also report more positive feelings about the impact of the green movement.

Research Question 3: Organizations that are described by employees as higher in organizational green orientation will also report more positive feelings about the organization's performance.

Research Question 4: Organizations that are described by employees as higher in organizational performance will also report more positive feelings about the impact of the green movement.

The depth or qualitative aspects of an organization's quality management functionality is referred to as QM maturity. In this research framework, we argue that companies that place green orientation on a higher priority will be more likely to prioritize the quality of QM implementation. In turn, employees will feel more positive about the sustainable impact they are making. The length of time an organization reports deploying quality management tools-and the caliber of the implementation from such tools-should influence employee perceptions about the overall company performance, and a stronger and greener culture should lead to more positive perceptions regarding organizational performance. (Research Questions 7, 8, 9, and 10, labeled as RQ7, RQ8, RQ9, and RQ10 in Figure 1). 
Research Question 7: Organizations that are described by employees as higher in organizational green orientation will also be described as having higher QM maturity.

Research Question 8: Organizations that are described by employees as higher in QM maturity will also report more positive feelings about the impact of the green movement.

Research Question 9: Organizations that are described by employees as higher in QM maturity will also report more positive feelings about the organization's performance.

Research Question 10: Organizations that are described by employees as higher in organizational culture will also be described as having higher QM maturity.

Figure 1. Research Model

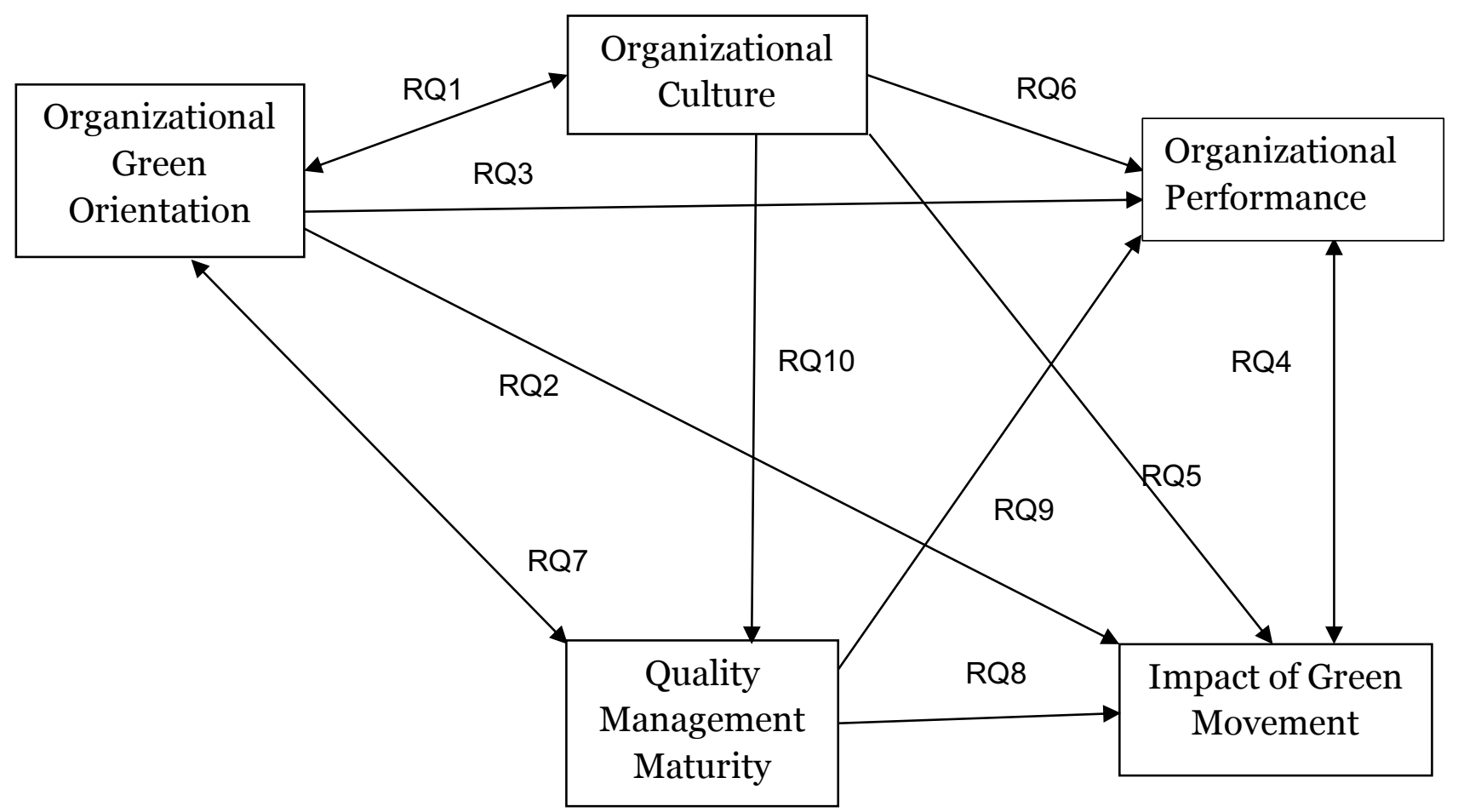

\section{Methodology}

\section{Sample Size and Data Analysis}

Based on Soper (2021), the sample size required is 848 if a structural equation model (SEM) is used for the analysis, but 174 is the required minimum sample size if simple regression/correlation is used for the analysis. The sample size of 331 was enough for the exploratory nature of this study, since Karl Pearson's Coefficient of Correlation was used to examine the relationships among the research variables. The assumptions and requirements for computing Pearson's Coefficient of Correlation were verified. First, skewness and kurtosis were checked for each item. Since the skewness and kurtosis values were within positive or negative 3, the variables in the study met the normality requirement. Second, scatter plots were set up for each pair of variables to ensure linear relationship. Last, testing for homoscedasticity was done by scatter plots with the 
research variable on the $y$-axis and the residual on the x-axis (Hair et al., 2019). The plots came up with consistent patterns and homoscedasticity was established.

\section{Subjects of the Study}

A total of 331 full-time employees from a wide variety of industries in the South were involved in the study. The subjects were roughly $51.7 \%$ male and $48 \%$ female with an average age of 41.49 . Among these 331 subjects, there are approximately nine categories of industries in our survey instrument. The three largest percentages of the subjects work in retail, health care, and manufacturing industries with $22.1 \%, 20.8 \%$, and $12.7 \%$, respectively. The results are shown in Table 1.

Table 1. Types of Industry

\begin{tabular}{|c|c|c|c|c|c|}
\hline \multicolumn{6}{|c|}{ Industry } \\
\hline & & Frequency & Percent & Valid Percent & $\begin{array}{l}\text { Cumulative } \\
\text { Percent }\end{array}$ \\
\hline \multirow[t]{10}{*}{ Valid } & Manufacturing & 42 & 12.7 & 12.7 & 12.7 \\
\hline & $\begin{array}{l}\text { Financial } \\
\text { services }\end{array}$ & 15 & 4.5 & 4.5 & $17 \cdot 3$ \\
\hline & Retail & 73 & 22.1 & 22.1 & 39.4 \\
\hline & Utilities & 9 & 2.7 & 2.7 & 42.1 \\
\hline & High technology & 7 & 2.1 & 2.1 & 44.2 \\
\hline & Education & 18 & $5 \cdot 4$ & $5 \cdot 5$ & 49.7 \\
\hline & Health care & 69 & 20.8 & 20.9 & 70.6 \\
\hline & Government & 5 & 1.5 & 1.5 & 72.1 \\
\hline & Other & 92 & 27.8 & 27.9 & 100.0 \\
\hline & Total & 330 & 99.7 & 100.0 & \\
\hline Missing & System & 1 & $\cdot 3$ & & \\
\hline Total & & 331 & 100.0 & & \\
\hline
\end{tabular}

Subjects responded to a survey that asked about their perceptions and experiences about the green movement, quality management, and organizational culture in their own firms. In this study, we will concentrate on the relationships among commitment to the green movement, quality management, organizational performance, and organizational culture.

\section{Instrument}

\section{Organizational Green Orientation}

Based on the previous research (Li et al., 2009), we measured the organizational sustainability by using the survey that provides 21 organizational green initiatives question items. The "Green Orientation" variable is a count of the total number of green sustainability initiatives implemented in an organization. 


\section{Quality Management (QM) Maturity}

In this study, QM maturity refers, in a qualitative sense, to the degree of QM implementation in an organization. We suggest, and previous research has shown (Ahire \& Golhar, 1996; Flynn et al., 1994; Fok et al., 2000, 2001; Patti et al., 2001; Saraph et al., 1989), that it can be measured by examining the perceived use of QM programs. These ideas assume that if an organization has more completely followed the QM philosophy, QM programs should be used throughout the organization and in various functional areas, rather than in isolation. Moreover, if "quality is indeed everyone's job," where QM is more fully in place, employees should be aware of the various TQM tools and techniques that are in use. If an organization, on the other hand, has very little or no experience with QM, the opposite is expected to occur. In earlier research (Fok et al., 2000, 2001; Patti et al., 2001), the process of developing a measure of QM maturity began, and the instrument developed dealt with perceived program use and asked respondents whether certain programs were in use in the organization, with a range from "not used" to "high usage."

In this study, consistent with earlier research, the QM maturity instrument was used to gauge QM maturity. An exploratory factor analysis (EFA) was used to identify the underlying dimensionality. Two factors emerged from the "Usage" items. The first factor appeared to include all the traditional quality management programs and was termed "Basic TQM Tools." The second factor was termed "Advanced TQM Tools," which includes programs like Six Sigma and Black Belt Training. Over 67\% of the variance (67.39\%) was explained by these two factors. Table 2 provides the items and results of the factor analysis.

Table 2. Factor Analysis on Quality Programs Usage Items

\begin{tabular}{lccr}
\hline \multicolumn{3}{c}{ Total Variance Explained } \\
\hline Component & Extraction Sums of Squared Loadings \\
& Total & \% of Variance & Cumulative \% \\
1 & 2.275 & 37.915 & 37.915 \\
2 & 1.768 & 29.475 & 67.39 \\
\hline
\end{tabular}

\begin{tabular}{lcc}
\hline Pattern Matrix & & \\
\hline & 1 & 2 \\
Quality management (QM) program & 0.643 & \\
Employee suggestion channels & 0.724 & \\
Employee quality training programs & 0.859 & \\
Quality improvement seminars & 0.775 & \\
Six Sigma programs & & 0.905 \\
Black Belt Training & & 0.955 \\
\hline
\end{tabular}

\section{Organizational Culture}

Based on previous research (Fok et al., 2000, 2001; Harman et al., 2009), organizational culture was measured by constructing a series of paired opposite items that asked whether the organization's climate should be described as open versus closed, soft versus tough, competitive versus collaborative, and the like. Table 3 provides the items and shows the results of EFA. A two-factor solution was obtained in the case of the organizational culture items and were labeled Factor 1, "Continuous Improvement Culture," and Factor 2, "People-Friendly Culture." Over 54 percent (54.27\%) of the variance was explained by these two factors. 
Fok et al., 2021

Table 3. Factor Analysis on Organizational Culture

\begin{tabular}{lccr}
\hline \multicolumn{3}{c}{ Total Variance Explained } \\
\hline Component & Extraction Sums of Squared Loadings \\
& Total & \% of Variance & Cumulative \% \\
1 & 2.626 & 37.517 & 37.517 \\
2 & 1.173 & 16.753 & 54.270 \\
\hline
\end{tabular}

\begin{tabular}{lrr}
\hline Pattern Matrix & & \\
& \multicolumn{1}{c}{ Component } & \\
Tough & 1 & 2 \\
Confrontational & & 0.864 \\
Team-Oriented & & 0.672 \\
Participative & 0.726 & \\
Quality-Oriented & 0.510 & \\
Innovation-Promoting & 0.740 & \\
Proactive & 0.762 & \\
\hline
\end{tabular}

\section{Organizational Performance}

The organizational performance items were primarily adapted from the Malcolm Baldridge National Quality Award outcome assessment measures. The Baldridge Awards are designed to identify organizations that are performing in an exceptional manner and include criteria for identifying excellence. The Baldridge criteria was used, in scale form, and asks respondents to provide perceptions about their organizations along Baldridge lines. The resulting scale has been used and reported in previous work (Fok et al., 2000, 2001; Hartman et al., 2009). The instrument includes items such as "Overall, my company is performing well," "Overall, morale in my company is high," "Overall, my company is productive," and the like. EFA indicated that one factor was present. The results showed that $56.205 \%$ of the variance was explained by the factor and it was named "Organizational Success."

\section{Impact of Green Movement}

The instrument included items such as "Provide better products," "Provide better services," "Have better relationship with customers," "Have better relationship with suppliers," "Have better reputation," "Provide better working environment," "Increase profits," "Reduce costs," and "Improve productivity" as a result of the green initiatives implemented in the organization. EFA produced a single-factor solution, and it was named "Impact of Green Movement." Over 70 percent (70.987\%) of the variance was explained by this factor.

\section{Reliability and Validity}

Various tests were done using SPSS and AMOS statistical programs to ensure the constructs were sound, reliable, and had no validity issues. First, Harman's one-factor test (Harman, 1976) was used to verify if there is common method bias. The first extracted factor from EFA explained $29.38 \%$ of the variance, which is lower than the $50 \%$ cutoff point. Consequently, it can confirm that common method bias is not found in this study.

Second, construct reliability and convergent validity were examined and summarized in Table 4. To establish construct reliability, both Cronbach's alpha and composite reliability (CR) were estimated. The Cronbach's alphas for all constructs are above 0.7, and the CRs are above o.6 (Sarstedt et al., 2017; Hair et al., 2019). Hence, 
the constructs in the research model have good construct reliability. Average variance extracted (AVE) was used to determine convergent validity. The AVE values for all constructs are greater than 0.5 and the loadings for each factor in the Pattern Matrix are greater than 0.5 (Benitez et al., 2020; Hair et al., 2019). The results indicate that convergent validity is achieved in this study. In addition, there are no strong cross loadings between factors; it provides evidence of discriminant validity.

Table 4. Construct Reliability and Convergent Validity

\begin{tabular}{lccr}
\hline Constructs & Cronbach's Alpha & $\begin{array}{c}\text { Composite } \\
\text { reliability (CR) }\end{array}$ & $\begin{array}{c}\text { Average variance } \\
\text { extracted (AVE) }\end{array}$ \\
\hline Green orientation & 0.923 & 0.812 & 0.520 \\
Organizational culture & 0.738 & 0.764 & 0.564 \\
QM maturity & 0.849 & 0.833 & 0.502 \\
Organization success & 0.880 & 0.928 & 0.696 \\
Impact of green movement & 0.949 & 0.802 & 0.742 \\
\hline
\end{tabular}

\section{Results}

The first research question examines the relationship between organizational green orientation and organizational culture. Table 5 provides the results of the correlation analysis. Two pairs of significant relationships were found. Both "Continuous Improvement Culture" and "People-Friendly Culture" have significant correlations with "Green Orientation," which implies that, as organizations embrace a culture that focuses on quality, team, and being proactive and employee-friendly, they also report higher levels of green orientation.

Table 5. Pearson's Correlation Matrix-Organizational Green Orientation, Organizational Culture, Organizational Performance, and Impact of Green Movement (RQ1, RQ2, RQ3, and RQ4)

\begin{tabular}{|c|c|c|c|c|c|}
\hline \multicolumn{6}{|c|}{ Correlations } \\
\hline & $\begin{array}{c}\text { Green } \\
\text { Orientation }\end{array}$ & $\begin{array}{l}\text { Continuous } \\
\text { Improvement } \\
\text { Culture }\end{array}$ & $\begin{array}{l}\text { People- } \\
\text { Friendly } \\
\text { Culture }\end{array}$ & $\begin{array}{l}\text { Organizational } \\
\text { Performance }\end{array}$ & $\begin{array}{l}\text { Impact of } \\
\text { Green } \\
\text { Movement }\end{array}$ \\
\hline Green Orientation & & & & & \\
\hline & - & $.127^{*}$ & $-.216^{* *}$ & $.414^{* *}$ & $.202^{* *}$ \\
\hline Continuous & & & & & \\
\hline $\begin{array}{l}\text { Improvement } \\
\text { Culture } \\
\text { People-Friendly }\end{array}$ & $.127^{*}$ & - & - & $.235^{* *}$ & $.582^{* *}$ \\
\hline Culture & $-.216^{* *}$ & - & - & $-.192^{* *}$ & NS \\
\hline $\begin{array}{l}\text { Organizational } \\
\text { Performance }\end{array}$ & $.414^{* *}$ & $.235^{* *}$ & $-.192^{* *}$ & - & $\cdot 313^{* *}$ \\
\hline $\begin{array}{l}\text { Impact of Green } \\
\text { Movement }\end{array}$ & $.202^{* *}$ & $.582^{* *}$ & NS & $.313^{* *}$ & - \\
\hline
\end{tabular}

${ }^{*}$ Correlation is significant at the 0.05 level (2-tailed); ${ }^{* *}$ correlation is significant at the 0.01 level (2-tailed), NS = not significant.

Research Question 2 (RQ2) suggests that organizations with higher levels of green orientation would be reported by the employees to have more positive feelings about the impact of the green movement. A significant and positive 
relationship was found between them. The results are shown in Table 5. The results support the premise that when organizations develop "green" products/services or use "green" material in the production; show more concern with avoiding negative consequences of not being green; and help their employees, at all levels, to be more greenoriented, the overall impact of these green initiatives is perceived to be more positive by the employees.

Research Question 3 (RQ3) suggests that organizations with higher levels of green orientation would have received more positive feelings about the organization's performance. The results are shown in Table 5. The relationship between "Green Orientation" and "Organizational Performance/Success" is significant at the .0oo level. The relationship is negative, which implies that as the organizations show more concern in helping their employees, at all levels, to be more green-oriented and pay more attention to safety concerns, the organizational performance is perceived by the employees to be higher.

Research Question 4 (RQ4) suggests that organizations with higher levels of organizational performance would be reported by the employees to have more positive feelings about the impact of the green movement. A significant relationship was found between them. The relationship is positive and implies that organizations with higher levels of performance would also be reported to have employees with more positive feelings about the impact of the green movement in their organizations.

Research Question 5 (RQ5) examines the relationship between organizational culture and impact of green movement. One pair of significant relationships was found in Table 6. "Continuous Improvement Culture" has a significant and positive correlation with "Impact of Green Movement." The finding indicates that as the organizational cultures are more team-oriented, participative, and proactive, the employees see more positive impacts from the green movement and feel overall more satisfied with green progress in their organizations.

Table 6. Pearson's Correlation Matrix-Organizational Culture, Impact of Green Movement, and Organizational Performance (RQ5 and RQ6)

\begin{tabular}{lllll}
\hline \multicolumn{5}{c}{ Correlations } \\
\hline & $\begin{array}{c}\text { Continuous } \\
\text { Improvement }\end{array}$ & $\begin{array}{c}\text { People- } \\
\text { Friendly }\end{array}$ & $\begin{array}{c}\text { Organizational } \\
\text { Performance }\end{array}$ & $\begin{array}{c}\text { Impact of Green } \\
\text { Movement }\end{array}$ \\
& Culture & Culture & & \\
Continuous Improvement Culture & - & - & $.235^{* *}$ & $.582^{* * *}$ \\
People-Friendly Culture & - & - & $-.192^{* * *}$ & $\mathrm{NS}$ \\
Organizational Performance & $.235^{* *}$ & $-.192^{* *}$ & - & $.313^{* *}$ \\
Impact of Green Movement & $.582^{* *}$ & $\mathrm{NS}$ & $.313^{* * *}$ & - \\
\hline${ }^{*}$ Correlation is significant at the 0.05 level (2-tailed); ${ }^{* * *}$ Correlation is significant at the 0.01 level (2-tailed), NS = not significant.
\end{tabular}

Research Question 6 (RQ6) suggests that organizations with higher levels of organizational culture would have received more positive reports about the organization's performance. The results are shown in Table 6. Two pairs of significant relationships are found. "Organizational Performance/Success" has significant correlations with both "Continuous Improvement Culture" and "People-Friendly Culture." The findings suggest that as the organizational cultures are more team-oriented and proactive and more employee-friendly, the organizational performance is perceived by the employees to be higher.

Research Question 7 (RQ7) examines the relationship between organizational green orientation and QM maturity. Table 7 provides the results of our correlation analysis. There are two pairs of significant relationships. The factor "Organizational Green Orientation" has significant and positive correlations with both "Use of Basic TQM Tools" and "Use of Advanced TQM Tools." The results confirm that when employees perceive that their 
organizations are more inclined to develop green products/services-and have a green workplace-they will be reported to have used higher levels of usage of both traditional and advanced TQM tools.

Table 7. Pearson's Correlation Matrix-Organizational Green Orientation, QM Maturity, and Impact of Green Movement (RQ7 and RQ8)

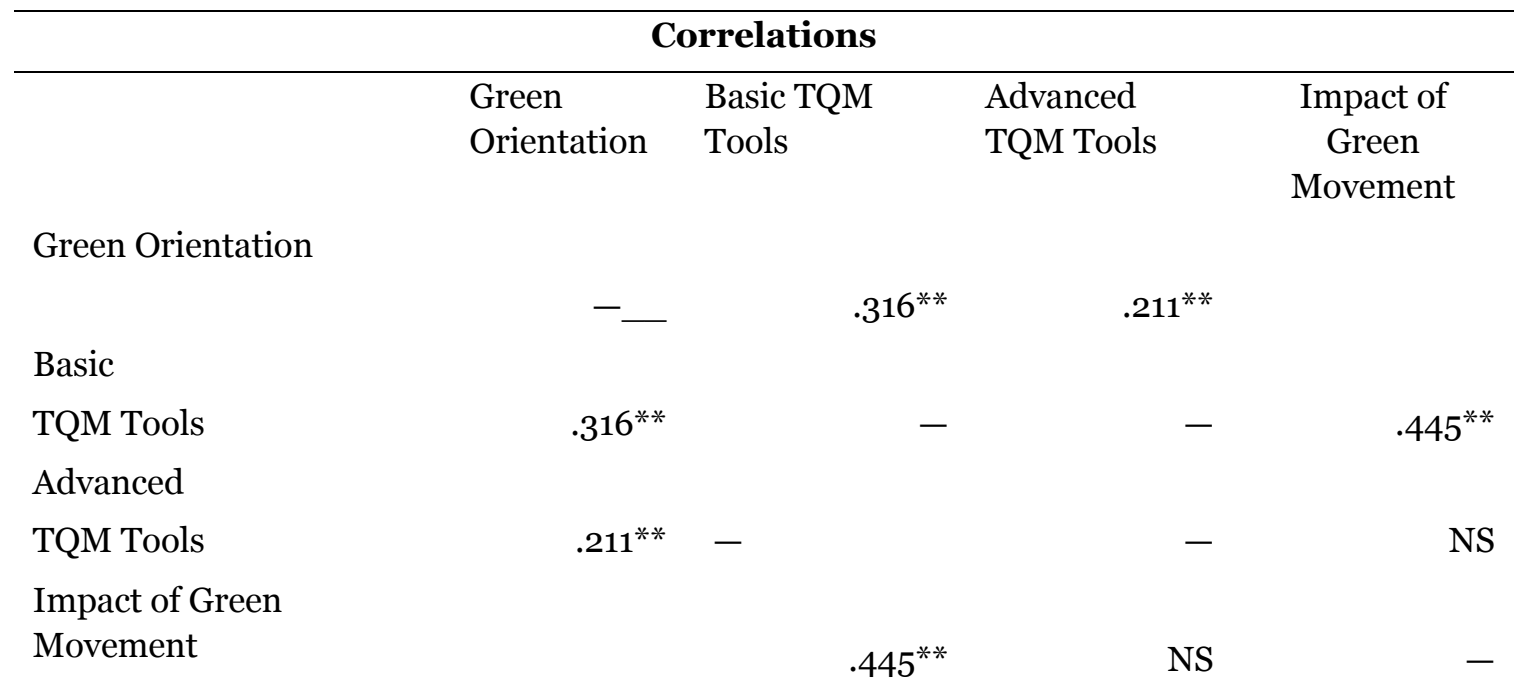

${ }^{*}$ Correlation is significant at the 0.05 level (2-tailed); ${ }^{* *}$ Correlation is significant at the 0.01 level (2-tailed), NS = not significant.

Research Question 8 (RQ8) examines the relationship between QM maturity and impact of green movement. Only one significant relationship was found in Table 7. "Use of Basic TQM Tools" has a significant and positive correlation with "Impact of Green Movement." The results suggest that organizations with higher levels of usage of traditional TQM tools would also have employees who report more positive feelings about the impact of the green movement and feel more satisfied with green progress in their organizations.

Research Question 9 (RQ9) suggests that organizations that are described by employees as higher in QM maturity will also have employees who report more positive feelings about the organization's performance. Both factors "Use of Basic TQM Tools" and "Use of Advanced TQM Tools" have significant and positive correlations with "Organizational Performance/Success." The results, as shown in Table 8, confirm that when employees report higher levels of organizational performance, they will also report higher levels of usage of both traditional and advanced TQM tools. 
Fok et al., 2021

Table 8. Pearson's Correlation Matrix-QM Maturity, Organizational Performance, and Organizational Culture (RQ9 and RQ1O)

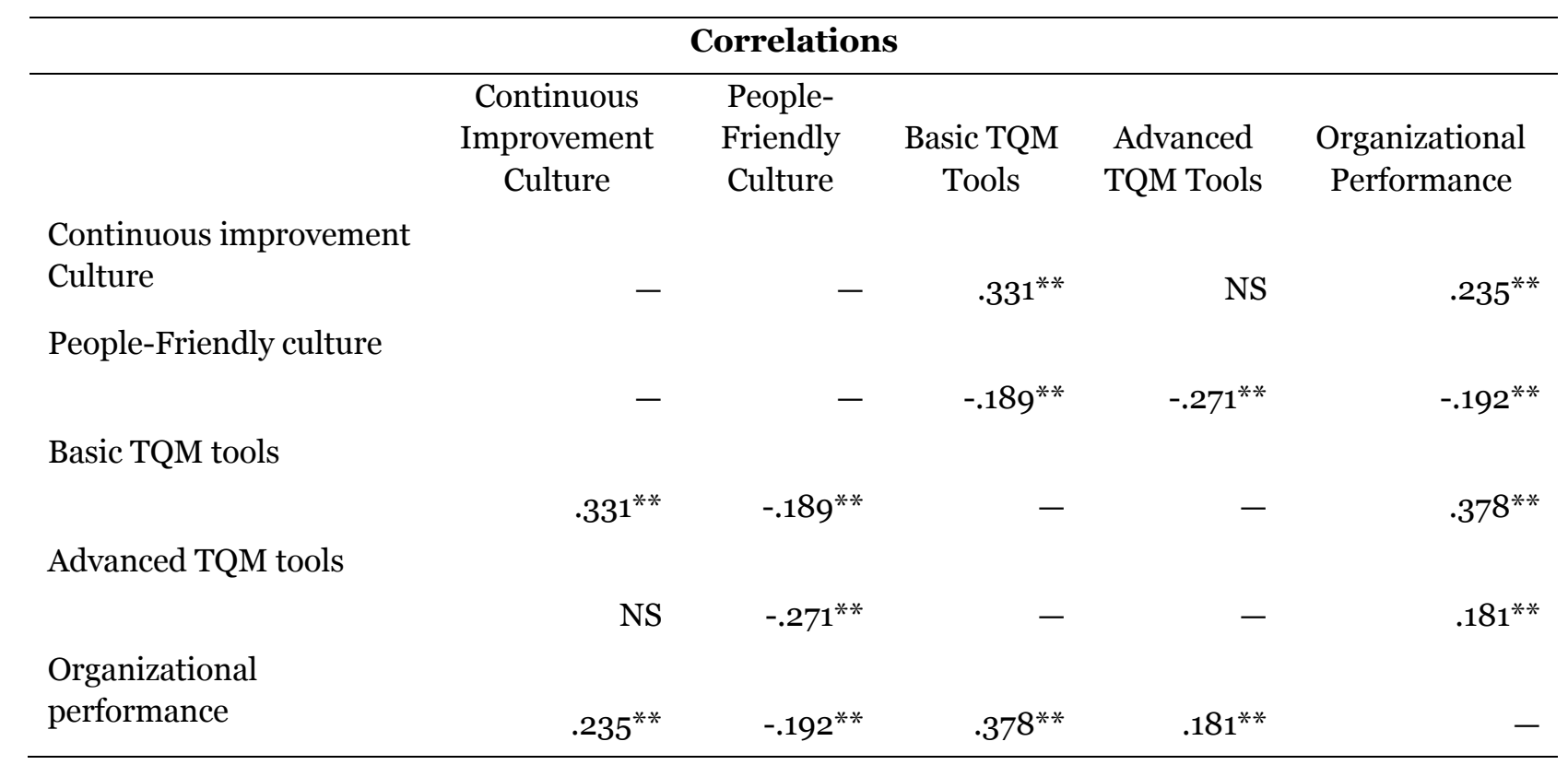

${ }^{* *}$ Correlation is significant at the 0.01 level (2-tailed); NS = not significant.

Research Question 10 (RQ10) suggests that organizations with a higher level of organizational culture would be reported by employees to have higher levels of QM maturity. Three pairs of significant relationships were found in Table 8. The relationship between "Continuous Improvement Culture" and "Use of Traditional TQM Tools" is significant at the .ooo level, which implies that as organizations embrace culture that focuses on quality, team, and being proactive, they also use more traditional TQM tools. "People-Friendly Culture" has significant relationships with "Use of Traditional TQM Tools" and "Use of Advanced TQM Tools." The findings indicate that, as the organizational cultures are reported to be more employee-friendly, employees will also report that their organizations have higher levels of usage of both traditional and advanced TQM tools. In general, the findings confirm that organizations with higher levels of organizational culture have used higher levels of usage of both traditional and advanced TQM tools.

\section{Discussion and Conclusions}

The pressure for businesses to protect and preserve the environment is mounting, and so is the pressure to compete internationally and thrive. It is increasingly pertinent for businesses to find ways to appease their stakeholders and customers with their green initiatives in all aspects of an organization across industries. In this research, we find substantial support for relationships among employee perceptions of organizational green orientation and various outcomes include impact of green movement, organizational performance, QM maturity, and organizational culture.

Employees who believe their organizations are green oriented, and place priority on sustainability, are more likely to perceive that their organizations exude higher performance, greater impact on the green movement, and have higher QM maturity. When individuals believe they work in an environment with a more cohesive and impactful organizational culture, they tend to feel more positive about their overall performance, QM maturity, and impact on eco-efficient efforts. Employees who perceive higher QM maturity in their organizations are also more likely to perceive being in an organization that has a greater impact on the green movement and performs 
better. Individuals rated their organizations as higher performing entities are likely to believe their companies have a more significant impact on the green movement.

Results suggest that the more informed employees are about what the company is doing to meet the new societal expectations of eco-friendliness, the more likely they are going to feel positive about various aspects of the organization. Potentially those positive feelings will lead to higher satisfaction and productivity. It is then logical to conclude that more education on a company's green initiatives should be provided to employees, because the dissemination of this information will be exceedingly helpful in building a strong organizational culture. A strong organizational culture that is supportive of the green movement, and in turn leads to positive organizational outcomes.

Undoubtedly, sustainability has become a major issue for many companies today. To truly make a big step towards becoming more sustainable, companies not only need to be concerned about their manufacturing processes, but greening their supply chains with green innovations are required, as well. It is imperative to find a balance among all three dimensions of sustainability: economical, environmental, and social. Being profitable and sustainable can be achieved when companies are willing to continuously pay attention to environmental issues and strategically invest in initiatives that are cost-efficient and eco-friendly.

Regarding the future, we recommended conducting follow-up studies to focus on several key industries, such as manufacturing, health care, retail, and finance and banking. A larger sample size would allow using a structural equation model (SEM) to establish directionality of construct variables and the development of industry specific sustainability strategies and best practices. In addition, a study based in a different geographical location (in the United States or a different country) is recommended to see if the findings can be generalized across different industries, geographical locations, or countries.

We also recommend that additional research be used to empiracally assess the social and environmental impacts of sustainability. While the top leaders of the companies set clear strategies and develop a supportive culture for sustainability and quality improvement to achieve financial gains, the new studies would capture additional impact data on different supply chain partners and the bigger ecosystem. Aligning one company's sustainability effort to others' in the entire supply chain may generate more substantial environmental and social impacts since the coordinated efforts benefit the same ecosystem. 


\section{References}

Ackerman, F. (1997). Why do we recycle? Markets, Values, and Public Policy. Island Press.

Ahire, S. L., \& Golhar, D. Y. (1996). Quality management in large versus small firms: An empirical investigation. Journal of Small Business Management, 34(2), 1-13.

Ahmad, S., \& Schroeder, R. G. (2002). The importance of recruitment and selection process for sustainability of total quality management. International Journal of Quality and Reliability Management, 19(5), $540-550$.

Beatley, T., \& Manning, K. (1997). The ecology of place: Planning for environment, economy, and community. Island Press.

Benitez, J., Henseler, J., Castillo, A., \& Schuberth, F. (2020). How to perform and report an impactful analysis using partial least squares: Guidelines for confirmatory and explanatory IS research. Information and Management, 57(2), 103-168. https://doi.org/10.1016/j.im.2019.05.003

Bergquist, A.-K. (2017). Business and sustainability: New business history perspectives (Working paper 18034). SSRN Electronic Journal.

https://www.researchgate.net/publication/320505845_Business_and_Sustainability_New_Busines s_History_Perspectives

Biotto, M., De Toni, A., \& Nonino, F. (2012). Knowledge and cultural diffusion along the supply chain as drivers of product quality improvement. The International Journal of Logistics Management, 23(2), 212-237. https://doi:10.1108/09574091211265369

Chin, K.-S., Pun, K.-F., \& Hua, H.-M. (2001). Consolidation of China's quality transformation efforts: A review. International Journal of Quality and Reliability Management, 18(8), 836-853. https://doi.org/10.1108/EUMooooooooo6032

Daily, B. F., \& Huang, S. (2001). Achieving sustainability through attention to human resource factors in environmental management. International Journal of Operations and Production Management, 21(12), 1539-1552. https://doi.org/10.1108/01443570110410892

Deif, A. M. (2011). A system model for green manufacturing. Journal of Cleaner Production, 19(14), 15531559. https://doi.org/10.1016/j.jclepro.2011.05.022

Dervitsiotis, K. N. (2001). Emerging elements of a world view for sustainable quality. Total Quality Management, 12(7/8), 817-824. https://doi.org/10.1080/09544120100000002

Doszhanov, A., \& Ahmad, Z. A. (2015). Customers' intention to use green products: The impact of green brand dimensions and green perceived value. SHS Web of Conferences, 18, Article 01008. https://www.researchgate.net/publication/281733955

Flynn, B. B., Schroeder, R. G., \& Sakakibara, S. (1994). A framework for quality management research and an associated measurement instrument. Journal of Operations Management, 11(4), 339-366. https://doi.org/10.1016/So272-6963(97)90004-8

Fok, L. Y., Fok, W. M., \& Hartman, S. J. (2001). Exploring the relationship between total quality management and information systems development. Information and Management, 38, 355-371.

Fok, L. Y., Hartman, S. J., Patti, A. L., \& Razek, J. R. (2000). The relationship between equity sensitivity, growth need strength, organizational citizenship behavior, and perceived outcomes in the quality environment: A study of accounting professionals. Journal of Social Behavior and Personality, 15(1), 99-120. 
Hair, J. F., Ringle, C. M., Gudergan, S. P., Fischer, A., Nitzl, C., \& Menictas, C. (2019). Partial least squares structural equation modeling-based discrete choice modeling: An illustration in modeling retailer choice. Business Research, 12(1), 115-142. https://doi.org/10.1007/s40685-018-0072-4

Hartman, S. J., Fok, L. Y., \& Zee, S. M. L. (2009). Linkage among employee perceptions of organizational commitment to the green movement and organizational culture, and their perceived impacts upon outcomes. Journal of Organizational Culture, Communications and Conflict, 13(2), 27-43.

Harman, H. H. (1976). Modern factor analysis (revised, 3rd ed.). The University of Chicago Press.

Hitchcock, D., \& Willard, M. (2002). Sustainability: Enlarging quality's mission. Quality Progress, 35(2), 4347.

Hoffman, A. J. (2000). Competitive environmental strategy: A guide to the changing business landscape (2nd ed.). Island Press.

Hofmann, A., \& Oldehaver, G. (2016). Vertically linked industries, product quality and minimum quality standards. German Economic Review, 17, 92-103. https://doi:10.1111/geer.12067

Jonker, J. (2000). Organizations as responsible contributors to society: Linking quality, sustainability and accountability. Total Quality Management, 11(4-6), 741-746. https://doi.org/10.1080/09544120050008156

Kangovou. (2017). The importance of eco-friendly products. https://www.kangovou.com/the-importance-ofeco-friendly-products

Klebnikoff, S. D. (1996). Eco-efficient leadership: The road to new business opportunities. Proceeding of the APO World Conference on Green Productivity (pp. 491-502). Manila, Philippines.

Laddha, S., \& Malviya, M. (2015). Green marketing and its impact on consumer buying behavior. NBR EJournal, 1(1), 1-7.

Lamvik, T., Low, M. K., Myklebust, O., \& Walsh, K. (2001). Manufacturing a green service: Engaging the TRIZ model of innovation. IEEE Transactions on Electronics Packaging Manufacturing, 24(1), 10-17. https://doi.org/10.1109/6104.924787

Li, J., Hartman, S. J., \& Zee, S. M. L. (2009). A study of green movement perceptions and behavioral intentions. International Journal of Sustainable Economy, 1(2), 133-143. https://doi.org/10.1504/IJSE.2009.023043

Li, J., Morrison, J., Zhang, M.T., Nakano, M., Biller, S., \& Lennartson, B. (2013). Automation in green manufacturing. IEEE Transactions on Automation Science and Engineering, 10(1), 1-4. https://10.1109/TASE.2012.2227582

Loffler, P. (1998). Sustainable development in Europe. A Cause for Regional Environment, 8, 113-120.

Ma, C., Liu, X., Zhang, H., \& Wu, Y. (2016). A green production strategies for carbon-sensitive products with a carbon cap policy. Advances in Production Engineering and Management, 11(3), 216-226. http://dx.doi.org/10.14743/apem2016.3.222

Macht, B., \& Davis, A. (2018). Strategies to influence a quality and compliance culture. International Journal of Applied Management and Technology, 17(1), 68-82. https://doi.org/10.5590/IJAMT.2018.17.1.06

Malik, A., \& Blumenfeld, S. (2012). Six sigma, quality management systems and the development of organisational learning capability: Evidence from four business process outsourcing organizations in India. International Journal of Quality and Reliability Management, 29(1), 71-91. https://doi.org/10.1108/02656711211190882

Matta, K. R(1996). Research questions on the implementation of total quality management. Total Quality Management, 7(1), 39-49. https://doi.org/10.1080/09544129650035034 
McAdam, R., \& Leonard, D. (2003). Corporate social responsibility in a total quality management context: Opportunities for sustainable growth. Corporate Governance, 3(4), 36-45. https://doi.org/10.1108/14720700310497104

Mokhtar, S. S. M., Abdullah, N. A. H., Kardi, N., \& Yacob, M. R. (2013). Sustaining a quality management system: Process, issues and challenges. Business Strategy Series, 14(4), 123-130. https://doi.org/10.1108/BSS-12-2011-0032

Patti, A. L., Hartman, S. J., \& Fok, L. Y. (2001). Investigating organizational quality management maturity: An investment validation study. International Journal of Quality and Reliability Management, 18(9), 882-899.

Polites, G. L., \& Karahanna, E. (2013). The embeddedness of information systems habits in organizational and individual level routines: Development and disruption. MIS Quarterly, 37(1), 221-246. https://doi:10.25300/misq/2013/37.1.10

Rapp, C., \& Eklund, J. (2002). Sustainable development of improvement activities-the long-term operation of a suggestion scheme in a Swedish company. Total Quality Management, 13(7), 945-969. https://doi.org/10.1080/0954412022000017049

Rashid, K., \& Aslam, M. M. (2012). Business excellence through total supply chain quality management. Asian Journal on Quality, 13(3), 309-324. https://doi:10.1108/15982681211287829

Sandu, R. (2014). Green: Marketing, products and consumers. SEA-Practical Application of Science, 2(3(5)), $555-562$.

Saraph, J. V., Benson, P. G., \& Schroeder, R. G. (1989). An instrument for measuring the critical factors of quality management. Decision Sciences, 2O(4), 810-829. https://doi.org/10.1111/j.15405915.1989.tbo1421.x

Sarstedt, M., Hair, J. F., Ringle, C. M., Thiele, K. O., \& Gudergan S. P. (2017). Estimation issues with PLS and CBSEM: Where the bias lies! Journal of Business Research, 69(10), 3998-4010. https://doi.org/10.1016/j.jbusres.2016.06.007

Schmiedel, T., vom Brocke, J., \& Recker, J. (2013). Which cultural values matter to business process management? Business Process Management Journal, 19(2), 292-317. https://doi:10.1108/14637151311308321

Sen, P. K., Bohidar, S. K., Shrivas, Y., Sharma, C., \& Modi, V. (2015). Study on innovation, research and recent development in technology for green manufacturing. International Journal of Mechanical Engineering and Robotics Research, 4(1), 185-194.

Sezen, B., \& Çankaya, S. Y. (2013). Effects of green manufacturing and eco-innovation on sustainability performance. Procedia-Social and Behavioral Sciences, 99, 154-163. https://doi.org/10.1016/j.sbspro.2013.10.481

Soper, D. (2021). A-priori sample size calculator for structural equation models. https://www.danielsoper.com/statcalc/calculator.aspx?id=89

Valmohammadi, C., \& Roshanzamir, S. (2015). The guidelines of improvement: Relations among organizational culture, TQM and performance. International Journal of Production Economics, 164, 167-178. https://doi:10.1016/j.ijpe.2014.12.028

Warren, G. E., \& Szostek, L. (2017). Small business strategies for sustainability beyond 10 years. International Journal of Applied Management and Technology, 16(1), 111-122. https://doi.org/10.5590/IJAMT.2017.16.1.07 
Whitelock, V. G. (2019). Multidimensional environmental social governance sustainability framework: Integration, using a purchasing, operations, and supply chain management context. Sustainable Development, 27(5), 923-931. https://doi.org/10.1002/sd.1951

Wilkinson, A., Hill, M., \& Gollan, P. (2001). The sustainability debate. International Journal of Operations and Production Management, 21(12), 1492-1502. https://doi.org/10.1108/01443570110410865

Wilson, T. (2011). Dollars and sense of green. The Canadian Manufacturing Online Magazine.

Yang, Y. C. (2017). Consumer behavior towards green products. Journal of Economics, Business and Management, 5(4), 160-167. https://doi.org/10.18178/joebm.2017.5·4.505

Yang, C.-L., Lin, S.-P., Chan, Y.-H., \& Sheu, C. (2010). Mediated effect of environmental management on manufacturing competitiveness: An empirical study. International Journal of Production Economics, 123(1), 210-220. https://doi.org/10.1016/j.ijpe.2009.08.017

Zairi, M. (2002). Beyond TQM implementation: The new paradigm of TQM Sustainability. Total Quality Management, 13(8), 1161-1172. https://doi.org/10.1080/09544120200000011

Zairi, M., \& Liburd, I. M. (2001, April 17-19). TQM sustainability-A roadmap for creating competitive advantage. Integrated Management, Proceeding of the 6th International Conference on ISO 9ooo and TQM (pp. 452-461). Paisley, Ayr, Scotland.

The International Journal of Applied Management and Technology (IJAMT), sponsored by Walden University's College of Management and Technology, is a peer-reviewed, online journal that addresses contemporary national and international issues related to management and technology. 